\title{
Synergistic Effect of Ionizing Radiation and B-lapachone against RKO Human Colon Adenocarcinoma Cells
}

\author{
Eun Jung Kim ${ }^{1}$, In-Mi Ji ${ }^{1}$, Ki-Jung Ahn, M.D. ${ }^{5}$, Eun Kyung Choi, M.D., Ph.D. ${ }^{2}$, Heon-Jin Park, Ph.D. ${ }^{3}$, \\ Byung Uk Lim, M.D., Ph.D. ${ }^{1}$, Chang W. Song, Ph.D. ${ }^{4}$ and Heon Joo Park, M.D., Ph.D. ${ }^{1}$
}

${ }^{1}$ Department of Microbiology, College of Medicine, Inha University, Incheon, Korea, ${ }^{2}$ Department of Therapeutic Radiology, College of Medicine, University of Ulsan, Seoul, Korea, ${ }^{3}$ Department of Statistics College of Medicine, Inha University, Incheon, Korea, ${ }^{4}$ Radiobiology Laboratory, Department of Therapeutic Radiology, University of Minnesota Medical School, Minneapolis, MN, USA, ${ }^{5}$ Department of Radiation Oncology, College of Medicine, Inje University, Busan, Korea

Purpose: To reveal the interaction between $\beta$-Lapachone ( $\beta$-lap) and ionizing radiation in causing cell death in RKO human colon adenocarcinoma cells, and to elucidate the potential usefulness of combined $\beta$-lap treatment and radiotherapy for cancer treatment.

Materials and Methods: The cytotoxicities of various treatments were determined in vitro using clonogenic and apoptotic cell death. The changes in cell cycle distribution were studied using flow cytometry and an in vitro kinase assay. The tumor growth was studied using RKO tumors grown s.c. in the hind leg BALB/c- nuslc nude mice.

Results: $\beta$-lap caused clonogenic cell death and rapid apoptosis in RKO cells in vitro, in a dose dependent manner. The repair of sublethal radiation damage was almost completely inhibited when cells were maintained in $\beta$-lap during the interval between the two-dose irradiation. Flow cytometry study demonstrated that $\beta$-lap

\section{INTRODUCTION}

$\beta$-Lapachone ( $\beta$-lap: 3, 4-dihydro-2, 2-dimethyl-2H-naphtho[1, 2-b]pyran-5, 6-dione) was originally extracted from the bark of the Lapacho tree (Tabebuia avellanedae) growing in South America (1), and has demonstrated cytotoxicity against various cancer cell lines $(1 \sim 7)$. It was previously proposed that $\beta$-lap kills cells by activation and/or inhibition of Topoisomerase I, inhibition of Topoisomerase II- $a$ and suppression of NF- $k B$

Correspondence: Heon Joo Park, Department of Microbiology, Inha University College of Medicine, 7-241, $3^{\text {rd }}$ St., Shinheung-dong, Jung-gu, Incheon 400-712, Korea. (Tel) 82-32-890-0953, (Fax) 82-32-881-8559, (E-mail) park001@inha.ac.kr

Received May 11, 2005, Accepted June 12, 2005

Work supported by grants of the National R\&D Program for Cancer Control, Ministry of Health \& Welfare, Republic of Korea (03203002), and 2003 KISTEP \& MOST, Korean government, through its National Nuclear Technology Program. induced apoptosis, independent of the cell cycle phase, and completely prohibited the induction of radiationinduced $\mathrm{G} 2$ arrest in irradiated cells. The prohibition of radiation-induced $\mathbf{G 2}$ arrest is unclear, but may be related to the profound suppression of the p53, p21 and cyclin B1-Cdc2 kinase activities observed in cells treated with $\beta$-lap. The combination of $\beta$-lap and radiation markedly enhanced the radiation-induced growth suppression of tumors.

Conclusion: B-lap is cytotoxic against RKO cells, both in vitro and in vivo, and also sensitized cells to ionizing radiation by inhibiting sublethal radiation damage repair. $\beta$-lap is potentially useful as a potent anti-cancer chemotherapy drug and potent radiosensitizer against caner cells. (Cancer Res Treat. 2005;37:183-190)

Key Words: $\beta$-Lapachone, lonizing radiation, NQ01, RKO cells, Radiosensitization

activity (1), but none of these have been demonstrated to play a significant role in $\beta$-lap-induced cell death in vivo.

Recently, NQO1 (NAD(P)H:quinone oxidoreductase) has been demonstrated to play a central role in the cell death caused by $\beta$-lap $(3,5,8)$. Like many other quinone compounds, $\beta$-lap is two-electron reduced to the hydroquinone form of $\beta$-lap, i.e. $\beta$-lap (HQ), through mediation of NQO1, utilizing NADH or $\mathrm{NAD}(\mathrm{P}) \mathrm{H}$ as the electron source (8). The resulting $\beta$-lap (HQ) is unstable, and oxidizes back to $\beta$-lap. This futile cycling between the oxidized and reduced forms of $\beta$-lap severely depletes the $\mathrm{NADH}$ or $\mathrm{NAD}(\mathrm{P}) \mathrm{H}$ levels $(3,5,8 \sim 10)$, which leads to a massive release of $\mathrm{Ca}^{2+}$ from the endoplasmic reticulum into the cytosol, the depletion of ATP and the release of mitochondrial cytochrome $\mathrm{C}(3,5,11)$. These chaotic molecular and metabolic changes trigger the signal transduction of apoptosis, including activation of $\mathrm{Ca}^{2+}$-dependent calpain or calpain-like proteases, thereby causing cleavage of vital proteins, such as p53 and PARP, and fragmentation of DNA (3, $5,8)$. Unlike the apoptosis caused by most DNA-damaging agents, the $\beta$-lap-induced apoptosis through the activation of calpain is unique in that caspases and p53 are not involved (2, 
$4,5,9)$. Another proposed mechanism underlying $\beta$-lap induced cell death is that $\beta$-lap (HQ) does not directly oxidizes to $\beta$ lap, but is oxidized to a one-electron reduced intermediate, i.e. semiquinone $\beta$-lap $(\mathrm{SQ}) \cdot$, which then generates cytotoxic reactive oxygen species (ROS) $(1,8)$. It has been reported that $\beta$-lap induces caspase-dependent apoptosis, probably through the production of ROS when the $\beta$-lap concentration is low (5). Another school of investigators proposed that $\beta$-lap causes apoptosis by activating cell cycle checkpoints, thereby perturbing cell cycle progression $(6,12,13)$.

In addition to killing cancer cells, $\beta$-lap has been reported to sensitize cancer cells to taxol (6), mitomycin C (MMC) (14) and genistein (15). Likewise, $\beta$-lap has been reported to sensitize cancer cells to ionizing radiation (IR; 7,16 18) by inhibiting the repair of potentially lethal damage (PLD) caused by radiation (7). We have recently observed that $\beta$-lap and ionizing radiation synergistically interact in causing clonogenic cells death even, when cells are treated with $\beta$-lap long after the radiation induced sublethal damage (SLD) has been repaired (19). In this connection, it was demonstrated that ionizing radiation causes an enduring increase in NQO1 activity $(19,20)$. Therefore, we concluded that irradiated cells become sensitive to $\beta$-lap due to the radiation-induced increase in NQO1 activity. However, the synergistic interaction between ionizing radiation and $\beta$-lap treatment, applied immediately after radiation exposure, may not be totally attributable to an increase in the NQO1 activity, as it takes several hours for a significant increase in the NQO1 activity after irradiation. The present study was undertaken to test our hypothesis that "when cells are treated with $\beta$-lap soon after irradiation, $\beta$-lap inhibits SLD repair, thereby increasing radiosensitivity of the cells."

\section{MATERIALS AND METHODS}

\section{1) Effect of $\beta$-lap and radiation alone or in combined} on the survival of RKO cells in vitro

$\beta$-Lap (3,4-dihydro-22,2-dimethyl-2H-naphthol [1,22b]pyran5,6-dione); purchased from a commercial source (Sigma, St Louis, MO), was dissolved in dimethyl sulfoxide to give a 10 $\mathrm{mM}$ stock solution, which was diluted to the desired concentrations in RPMI 1,640 medium and used to the treat cells. RKO human colon adenocarcinoma cells were used through out the present study. Cells were maintained in DMEM medium (GIBCO BRL, Grand Island, NY), supplemented with 10\% bovine calf serum (Hyclone Laboratories Inc. Logan, UT), penicillin (50 units $/ \mathrm{ml}$ ) and streptomycin $(50 \mu \mathrm{g} / \mathrm{ml})$, at $37^{\circ} \mathrm{C}$ in a humidified $95 \%$ air-5\% $\mathrm{CO}_{2}$ atmosphere. For the experiments, cells in the exponential growth phase were dispersed to single cells by treatment with $0.25 \%$ trypsin for $10 \mathrm{~min}$, washed twice with medium containing $10 \%$ bovine calf serum, and appropriate numbers of cells seeded in $25 \mathrm{~cm}^{2}$ plastic tissue culture flasks with $5 \mathrm{ml}$ of DMEM medium. After overnight incubation at $37^{\circ} \mathrm{C}$, the cells were treated with $\beta$-lap alone, IR alone or with both in combination. Cells were irradiated with a ${ }^{137} \mathrm{Cs}$ irradiator (Model 68, J.L. Shepherd and Associates, Glenwood, CA) at a dose rate of $0.9 \mathrm{~Gy} / \mathrm{min}$.

(1) Clonogenic survival: The cells treated with $\beta$-lap and irradiation alone or in combination were washed twice with drug-free medium, cultured for $7 \sim 8$ days, colonies fixed with a mixture of methanol and acetic acid $(10: 1 \mathrm{v} / \mathrm{v})$ and then stained with $1 \%$ crystal violet. Colonies containing more than 50 cells were scored.

(2) Apoptosis: The cells treated with $\beta$-lap and irradiation alone or in combination were harvested with trypsin treatment, washed with PBS and treated overnight with lysis buffer (10 $\mathrm{mM}$ Tris- $\mathrm{HCl}, \mathrm{pH} 7.4 ; 10 \mathrm{mM} \mathrm{NaCl} ; 10 \mathrm{mM}$ EDTA; proteinase $\mathrm{K}$ at $0.1 \mathrm{mg} / \mathrm{ml} ; 1 \%(\mathrm{w} / \mathrm{v}) \mathrm{SDS})$ at $48^{\circ} \mathrm{C}$. The lysate was mixed with cold $\left(4^{\circ} \mathrm{C}\right) 5 \mathrm{M} \mathrm{NaCl}$ solution, the mixture vortexed for several seconds and then centrifuged at $10,000 \times \mathrm{g}$ for $5 \mathrm{~min}$. The supernatant was mixed with isopropanol $(1: 1)$ and stored overnight at $-20^{\circ} \mathrm{C}$. After centrifugation at $12,000 \times \mathrm{g}$ for 20 $\mathrm{min}$, the pellet was resuspended in TE buffer $(10 \mathrm{mM}$ Tris- $\mathrm{HCl}$ $\mathrm{pH} 7.4,1 \mathrm{mM}$ EDTA) and the RNA digested by the addition of $0.2 \mathrm{mg} / \mathrm{ml}$ DNase-free RNase. A15 20 $\mu \mathrm{g}$ aliquot of DNA from each sample, as well as the DNA molecular weight marker, were subjected to electrophoresis on $1.5 \%$ agarose gel in TBE ( $89 \mathrm{mM}$ Tris base, $89 \mathrm{mM}$ boric acid, $2 \mathrm{mM}$ EDTA) and the DNA stained with ethidium bromide (21).

\section{2) Effects of $\beta$-lap on sublethal radiation damage repair}

The sublethal radiation damage repair was assessed by irradiating cells with $6 \mathrm{~Gy}$, either in a single dose or in 2 doses of $3 \mathrm{~Gy}$ at a $1 \mathrm{~h}$ interval. In order to reveal the effect of $\beta$-lap on the sublethal damage repair, the medium was replaced with $8 \mu \mathrm{M}$ B-lap immediately after the first 3 Gy irradiation dose, incubated for $1 \mathrm{~h}$ at $37^{\circ} \mathrm{C}$, and the cells washed twice with regular medium immediately after the second 3 Gy irradiation dose. After culturing for $7 \sim 8$ days, the clonogenic survival was determined and the magnitude of repair of sublethal damage (SLD) estimated (22).

\section{3) Flow cytometric analysis of cell cycle distribution}

Cells were harvested by trypsin treatment, fixed overnight with $80 \%(\mathrm{v} / \mathrm{v})$ ethanol at $4^{\circ} \mathrm{C}$, centrifuged, washed with PBS and suspended in $2 \mathrm{ml}$ of PBS containing 30 units of DNasefree RNase. A $100 \mu \mathrm{l}$ aliquot, containing $5 \mu \mathrm{g}$ propidium iodide (PI), was added to the cell suspension, mixed, stored in the dark at $37^{\circ} \mathrm{C}$ for $1 \mathrm{~h}$ and kept covered until the fluorescence was measured using a FACSCalibur flow cytometer (Becton Dickinson, San Jose, CA). The fractions of cells in each cell cycle phase, or those undergoing apoptosis, were estimated from the cellular DNA contents (21).

\section{4) Western blot analysis for p53 and p21}

Cells were washed twice with ice-cold PBS and dissolved in solubilizing buffer $(\mathrm{pH} 7.4,1 \%$ Triton X-100, 0.1\% SDS, $20 \mathrm{mM}$ Tris-HCl, $150 \mathrm{mM} \mathrm{NaCl}$, I mM EDTA, $1 \mathrm{mM}$ sodium orthovanadate, $1 \mathrm{mM}$ sodium fluoride, $2 \mathrm{mM}$ PMSF, $10 \mathrm{mM}$ iodoacetamide, $10 \mu \mathrm{g} / \mathrm{ml}$ aprotinin and $10 \mu \mathrm{g} / \mathrm{ml}$ leupeptin). Aliquots, containing 50 $\mathrm{\mu g}$ of protein, were separated using 7.5 $\%$ SDS-PAGE. Separated polypeptides were then transblotted onto Hybond-P (Amersham Life Sciences, Inc., Arlington Heights, IL) in transfer buffer (192 mM glycine, $25 \mathrm{mM}$ SDS and $10 \%$ methanol). The blots were blocked with $3 \%$ non-fat dried milk in $\mathrm{pH} 7.4$ TBST. The following mouse monoclonal antibodies were used to probe the Western blots: anti-p53 (1 $\mathrm{\mu g} /$ $\mathrm{ml}$; Oncogene Research Products, Cambridge, MA) and anti- 
p21 (1 $\mu \mathrm{g} / \mathrm{ml}$; UBI, Lake Placid, NY). Horseradish peroxidaseconjugated second antibody was used for visualization (1: 2000; Amersham, Piscataway, NJ). Equal sample loading was confirmed by reprobing the same blots with mouse monoclonal antiserum against alpha-tubulin $(21,23)$.

\section{5) Cyclin B1-Cdc2 kinase activity}

Cells were harvested with trypsin and lysed in 500ul of $1 \%$ NP-40 buffer (pH 7.4, 1\% NP-40, 0.1\% SDS, $20 \mathrm{mM}$ Tris-HCl, $150 \mathrm{mM} \mathrm{NaCl}, 1 \mathrm{mM}$ EDTA, $1 \mathrm{mM}$ sodium orthovanadate, $1 \mathrm{mM}$ sodium fluoride, $2 \mathrm{mM}$ PMSF, $10 \mathrm{mM}$ iodoacetamide, $10 \mu \mathrm{g} / \mathrm{ml}$ aprotinin and $10 \mu \mathrm{g} / \mathrm{ml}$ leupeptin). Lysates were centrifuged twice at $12,000 \times \mathrm{g}$ for $15 \mathrm{~min}$ each at $4^{\circ} \mathrm{C}$ and then immunoprecipitated with mouse monoclonal anti cyclin $\mathrm{B} 1$ antibody for $2 \mathrm{~h}(200 \mu \mathrm{g}$ lysates, $1 \mu \mathrm{g} / \mathrm{ml}$ antibody: UBI, Lake Placid, NY). The resulting immune complexes were collected with 50ul of protein G-plus/protein A-agarose (Oncogene Research Products, Boston, MA), washed 4 times with 1\% NP40 buffer and then equilibrated with kinase buffer $(50 \mathrm{mM}$ Tris$\mathrm{Cl}, \mathrm{pH} 7.4,10 \mathrm{mM} \mathrm{MgCl} 2,1 \mathrm{mM}$ DTT). Each sample was incubated at $30^{\circ} \mathrm{C}$ for $30 \mathrm{~min}$ with $50 \mu \mathrm{g} / \mathrm{ml}$ histone H1 (Roche

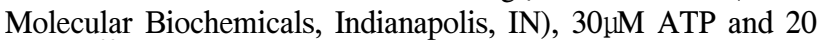
$\mu \mathrm{Ci}\left[\gamma^{32} \mathrm{P}\right]$ ATP (ICN, Costa Mesa, CA). The kinase activity was terminated by the addition of an equal volume of $2 \times$ SDSsample buffer, the reaction mixtures resolved on 12\% SDSpolyacrylamide gels, the kinase activity visualized by autoradiograph and quantitated with a scintillation $\beta$-counter (21).

6) Effect of $\beta$-lap alone or in combination with $\mathrm{X}$-irradiation on tumor growth

Cells in the exponential growth phase were harvested, and about $2 \times 10^{5}$ cells, suspended in $0.05 \mathrm{ml}$ serum free medium, were injected s.c. into the right hind leg of BALB/c-nuslc nude mice weighing $20 \sim 25 \mathrm{~g}$. When tumors had grown to $7 \sim 8 \mathrm{~mm}$ in diameter, a group of mice were i.p. injected with $24 \mathrm{mg} / \mathrm{kg}$ $\beta$-lap dissolved in $0.2 \mathrm{ml}$ serum free medium. Another group of mice bearing tumors were treated with $20 \mathrm{~Gy} \mathrm{X}$-irradiation in a single exposure. The third group of tumor bearing mice received combined treatment; mice were injected, i.p., with $\beta$ lap, at $24 \mathrm{mg} / \mathrm{kg}$, and the tumors treated with $20 \mathrm{~Gy} \mathrm{X}$-irradiation $30 \mathrm{~min}$ after the drug injection. The mice, which did not receive a $\beta$-lap injection, received an injection of $0.2 \mathrm{ml}$ medium only. For the irradiation of tumors grown in the thigh, mice were anesthetized with an i.p. injection of a mixture of 100 $\mathrm{mg} / \mathrm{kg}$ ketamine and $10 \mathrm{mg} / \mathrm{kg}$ xylazine. The whole-bodies of the anesthetized mice were covered with a $4 \mathrm{~mm}$ thick lead shield, except for the tumor area, and the tumors irradiated with $220 \mathrm{kV}$ orthovoltage X-rays (added filtration of $1.0 \mathrm{~mm} \mathrm{Al}$ and $0.25 \mathrm{~mm} \mathrm{Cu}$ ) (Philips Medical System, Brookfield, WI) at 1.4 $\mathrm{Gy} / \mathrm{min}$. The tumor diameters were measured with calipers, and the volumes calculated using the formula: $V=a^{2} b / 2$, where ' $a$ ' and ' $b$ ' was the shortest and longest tumor diameters measured, respectively. For each experimental group, 6 $\sim 7$ tumors were used, and the average volumes obtained. The mice were euthanized by cervical dislocation, under anesthesia, when the tumor size reached about $1.5 \mathrm{~cm}^{3}(24)$.

\section{RESULTS}

\section{1) Effect of $\beta$-lap on the clonogenicity of RKO cells}

Fig. 1 shows the percentage survival of clonogenic RKO cells treated with $2.5 \sim 10 \mu \mathrm{M}$ of $\beta$-lap for 4 hours. The clonogenic cell survival decreased, in a dose dependent manner. Incubation of cells with $10 \mu \mathrm{M}$-lap for $4 \mathrm{~h}$ decreased the cells survival to about $2.9 \%$.

\section{2) Radiosensitization of cells by $\beta$-Lap}

Fig. 2 shows the survival curve for cells treated with ionizing radiation alone, and those for cells irradiated and treated with 5 or $10 \mu \mathrm{M}$ B-lap for $4 \mathrm{~h}$, starting soon after the radiation exposure. The survival curves were normalized for the cell death caused due to $\beta$-lap treatment alone. The $\mathrm{D}_{0}$ of the survival curves for the radiation exposure alone was $1.9 \mathrm{~Gy}$, while those for the cells treated with radiation and 5 or $10 \mu \mathrm{M}$ $\beta$-lap were 1.3 and $1.1 \mathrm{~Gy}$, respectively.

\section{3) Inhibition of sublethal radiation damage repair by $\beta$-lap}

As shown in Fig. 3, irradiation with 6 Gy in a single dose reduced the cell survival to $5.54 \%$, while 6 Gy irradiation in two 3 Gy doses separated by $1 \mathrm{~h}(3 \mathrm{~Gy}+3 \mathrm{~Gy})$ resulted in $14.1 \%$ survival. This increase, from 5.54 to $14.1 \%$, in cell survival by splitting the radiation into two equal doses was assumed to be due to the repair of sublethal radiation damage. When cells were maintained in $8 \mu \mathrm{M}$ B-lap solution during the $1 \mathrm{~h}$ interval between the two 3 Gy irradiation exposures ( $3 \mathrm{~Gy}$ $+3 \mathrm{~Gy}+\beta$-lap), the cell survival decreased to $4.59 \%$. When

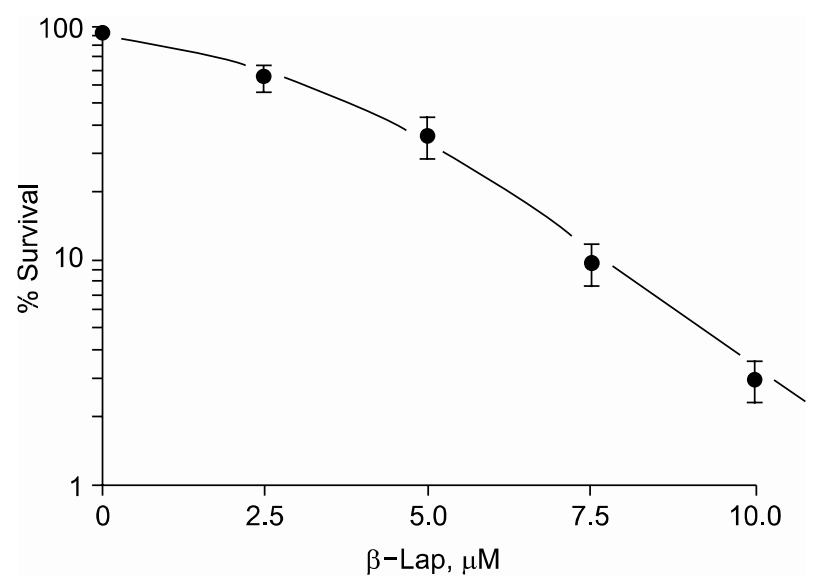

Fig. 1. Cytotoxicity of $\beta$-lap on RKO tumor cells. Cells were incubated with different concentrations of $\beta$-lap at $37^{\circ} \mathrm{C}$ for varying lengths of time, rinsed with fresh medium, and cultured for $8 \sim 9$ days with regular medium. The numbers of colonies formed with more than 50 cells were counted, and the \%age survival calculated. Each data point shows an average of 7 experiments, from duplicate cultures \pm 1 S.E. 
the $4.59 \%$ survival was normalized for the cell death caused by $1 \mathrm{~h}$ treatment with $8 \mu \mathrm{M}$ $\beta$-lap, i.e., $78.1 \%$, the $4.59 \%$ survival was equivalent to of $5.80 \%$. Note: this $5.80 \%$ survival was similar to $5.54 \%$ survival obtained after a single 6 Gy irradiation dose. It was apparent that the maintenance of cells in $8 \mu \mathrm{M}$-lap solution during the interval between the two radiation exposures almost completely inhibited the repair of sublethal radiation damage.

\section{4) Induction of apoptotic DNA degradation in vitro}

Fig. 4 shows that irradiation with 2 or 4 Gy caused little apoptotic DNA fragmentation in $24 \mathrm{~h}$. Conversely, significant

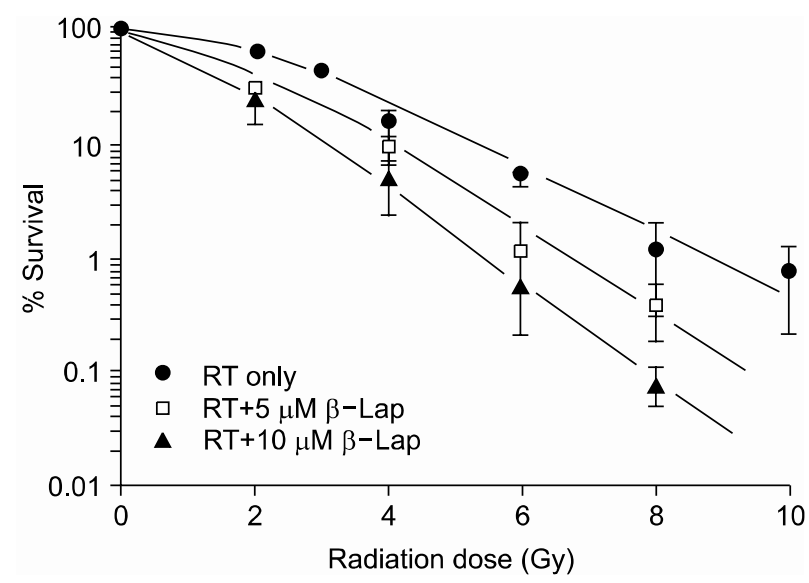

Fig. 2. Survival curves for the RKO tumor cells treated with radiation alone (RT only), or with $\beta$-lap treatment. Cells were irradiated, incubated with 5 or $10 \mu \mathrm{M}$-lap for $4 \mathrm{~h}$ (RT+ B-lap) and rinsed. After culturing for 8-9 days, the numbers of were colonies counted and the \%age survival calculated. An averages of 5 7 experiments, from duplicate cultures \pm 1 S.E., are shown.
DNA degradation occurred by $8 \mathrm{~h}$, i.e. $4 \mathrm{~h}$ after $4 \mathrm{~h}$ incubation with $\beta$-lap. Extensive DNA smears occurred at 16 and $24 \mathrm{~h}$ in the $\beta$-lap-treated cells, suggesting that the cells were in late apoptosis and undergoing necrotic DNA degradation. The degradation of DNA in the cells irradiated with 2 or $4 \mathrm{~Gy}$, and immediately treated with $\beta$-lap, were similar to that of the cells treated with $\beta$-lap alone, indicating the apoptotic death that occurred during the first $24 \mathrm{~h}$ after irradiation followed by $\beta$ lap treatment was mainly due to the $\beta$-lap treatment.

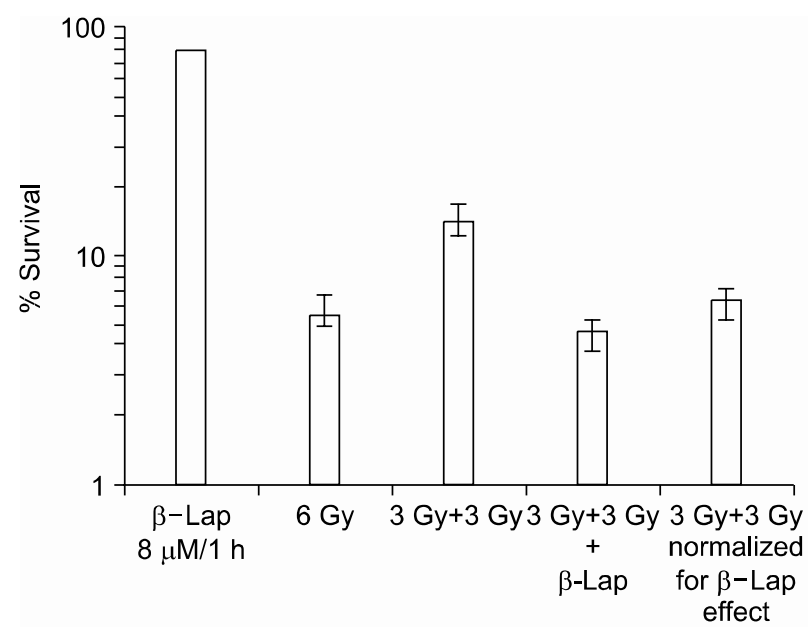

Fig. 3. Effect of $\beta$-lap on the repair of sublethal damage (SLD) due to radiation. Cells were irradiated with $6 \mathrm{~Gy}$ in a single exposure or with two $3 \mathrm{~Gy}$ exposures, at $1 \mathrm{~h}$ interval in regular media $(3 \mathrm{~Gy}+3 \mathrm{~Gy})$, or in the presence of $8 \mu \mathrm{M}$ $\beta$-lap, between the 2 radiation dose exposures $(3 \mathrm{~Gy}+3$ Gy+ $\beta$-lap). The survivals of the cells exposed to $8 \mu \mathrm{M}$ $\beta$-lap during the $1 \mathrm{~h}$ interval between the two irradiation doses were normalized for the cell death caused by $\beta$-lap. The means of 5 experiments, with one S.E., are shown.

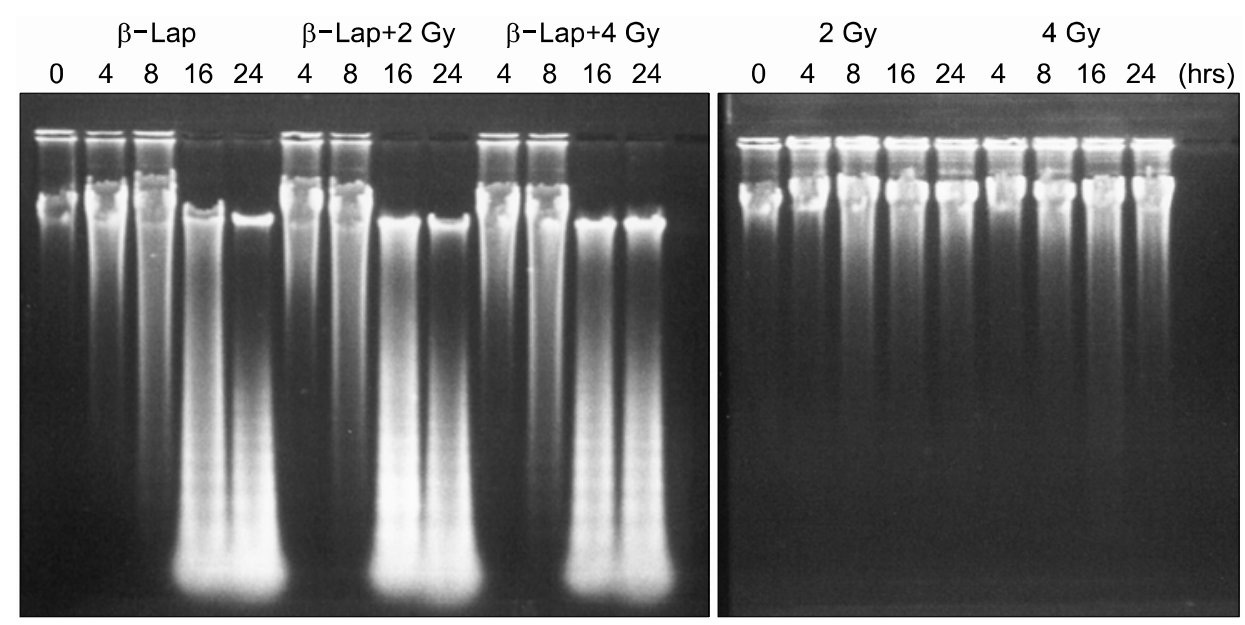

Fig. 4. Apoptotic DNA degradation in RKO tumors cells treated with $\beta$-lap alone, irradiation alone and in combination. For the combined effect, the cells were first irradiated and then incubated with $5 \mu \mathrm{M} \beta$-lap for $4 \mathrm{~h}$. Therefore, the ' $4 \mathrm{~h}$ ' represents $4 \mathrm{~h}$ after irradiation or $0 \mathrm{~h}$ after the $4 \mathrm{~h}$-lap treatment. 


\section{A}

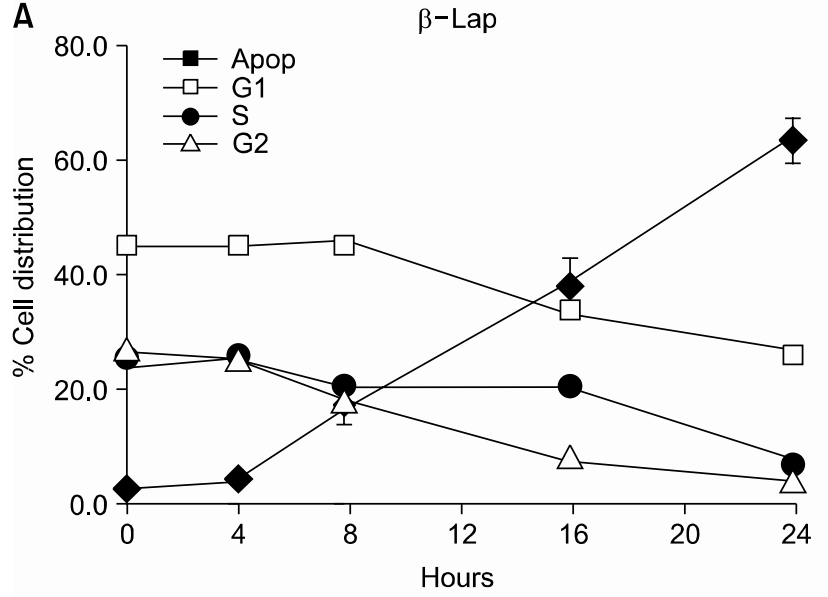

C

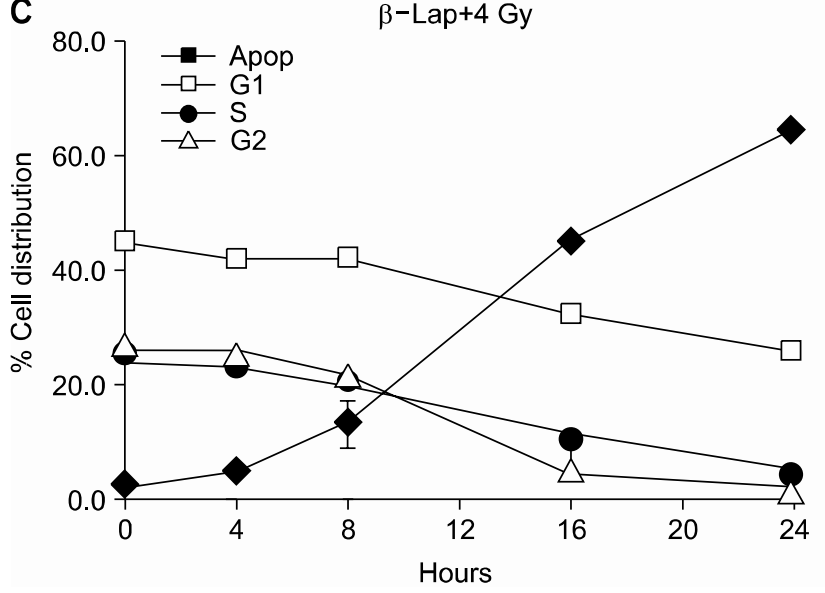

5) Effect of $\beta$-lap and irradiation on cell cycle distribution

Fig. 5 shows the changes in the percentage of cells in different cell cycle phases, averaged from 4 repeated flow cytometry experiments. Irradiation with 4 Gy rapidly increased the G2/M cell population from $25 \%$ in control cells to almost $60 \%$ in 4 $\mathrm{h}$. The G2/M cell population then began to decline slowly 16 $\mathrm{h}$ after irradiation. The G1 cell population decreased for $4 \mathrm{~h}$, slightly recovered thereafter, and further recovered $16 \mathrm{~h}$ after irradiation. The $\mathrm{S}$ cell population continuously declined for 8 $\mathrm{h}$, and remained decreased until $24 \mathrm{~h}$ post irradiation. When cells were treated with $5 \mu \mathrm{M} \beta$-lap for $4 \mathrm{~h}$, the cell population in the sub-G1 phase, i.e. apoptotic cells, began to increase steadily from $4 \mathrm{~h}$, i.e. at the end of $4 \mathrm{~h}$ incubation with $\beta$-lap, and reaching about $60 \%$ of the total cell population at $24 \mathrm{~h}$. Such a marked increase in the apoptotic cell population occurred at the expense of declines in the G1, S and G2/M cell populations. The rates of decline of the cell populations in the G1 and G2/M phases were almost similar, while that for the $\mathrm{S}$ cell population was slightly slower than those of the G1 and G2/M cells. The increase in the apoptotic cell population and decrease in the cell populations in the G1, S and G2/M phases in the irradiated cells immediately treated with $\beta$-lap were almost identical to those in the cells that had received the $\beta$-lap

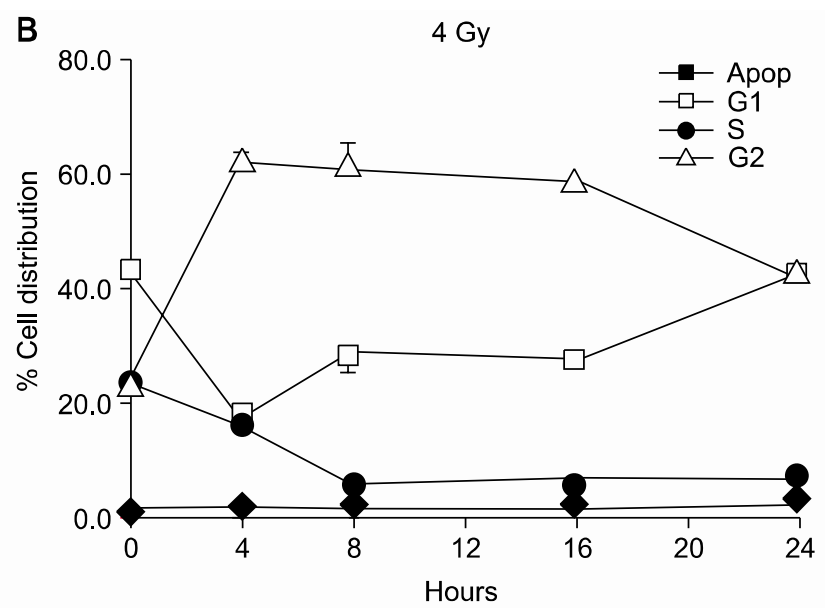

Fig. 5. Flow cytometric analyses of the cell cycle distribution after irradiation alone, B-lap treatment alone and in combination. For the combined effect, the cells were first irradiated and then incubated with $5 \mu \mathrm{M}$ B-lap for $4 \mathrm{~h}$. Therefore, the ' $4 \mathrm{~h}$ ' represents $4 \mathrm{~h}$ after irradiation or 0 $\mathrm{h}$ after the $4 \mathrm{~h}$-lap treatment. The means of 4 experiments, with one S.E., are shown.

treatment alone. Note: radiation-induced G2/M arrest did not occur when cells were treated with $\beta$-lap soon after the 4 Gy irradiation, demonstrating that $\beta$-lap treatment completely prohibited the induction of radiation-induced G2 arrest.

\section{6) Effects of $\beta$-lap on p53, p21and cyclin B1/Cdc2 kinase}

Fig. 6 shows the effects of $\beta$-lap on the expressions of p53 and $\mathrm{p} 21$, which are known to be intimately involved in cell cycle progression and apoptosis. Irradiation with 2 or 4 Gy significantly increased the p53 expression during the $24 \mathrm{~h}$ postirradiation period. Conversely, treatment of cells with $5 \mu \mathrm{M} \beta$ lap markedly suppressed the expressions of p53 and p21, particularly $16 \sim 24 \mathrm{~h}$ after the treatment. The expressions of p53 and p21 in the cells irradiated and treated with $\beta$-lap were similar to those in the cells treated with $\beta$-lap alone.

The cyclin B1/Cdc2 kinase activity progressively increased after the 4 Gy irradiation, but decreased after the $\beta$-lap treatment. The cyclin B1/Cdc2 kinase activity in the cells irradiated and treated with $\beta$-lap also decreased, similarly to those treated with $\beta$-lap alone.

\section{7) Combined effect of irradiation and $\beta$-lap on the} growth of RKO tumors in vivo

Fig. 7 shows the growth curves of RKO tumors treated with $10 \mathrm{~Gy}$ irradiation alone and with an i.p. injection of $24 \mathrm{mg} / \mathrm{kg}$ 


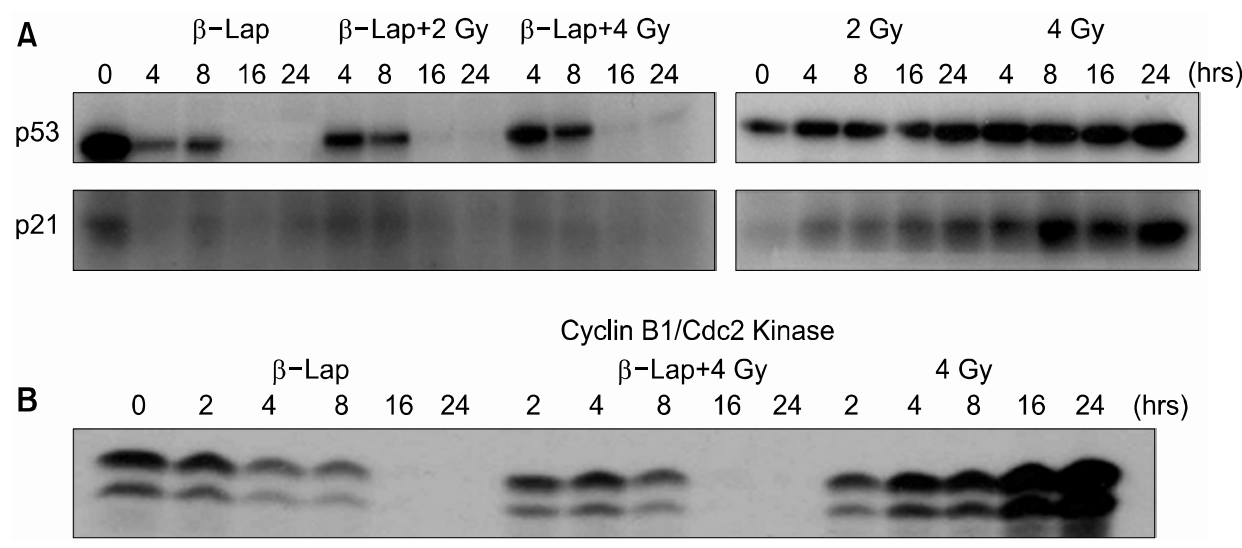

Fig. 6. The activities of $\mathrm{p} 53$ and $\mathrm{p} 21$ (A), and that of cyclin B1/Cdc2 kinase (B), in the cells treated with irradiation lone, $\beta$-lap alone and in combination. For the combined effect, the cells were first irradiated and then incubated with $5 \mu \mathrm{M} \beta$-lap for $4 \mathrm{~h}$. Therefore, the ' $4 \mathrm{~h}$ ' represents $4 \mathrm{~h}$ after irradiation or $0 \mathrm{~h}$ after the $4 \mathrm{~h}$-lap treatment. Representative results from 4 studies are shown.

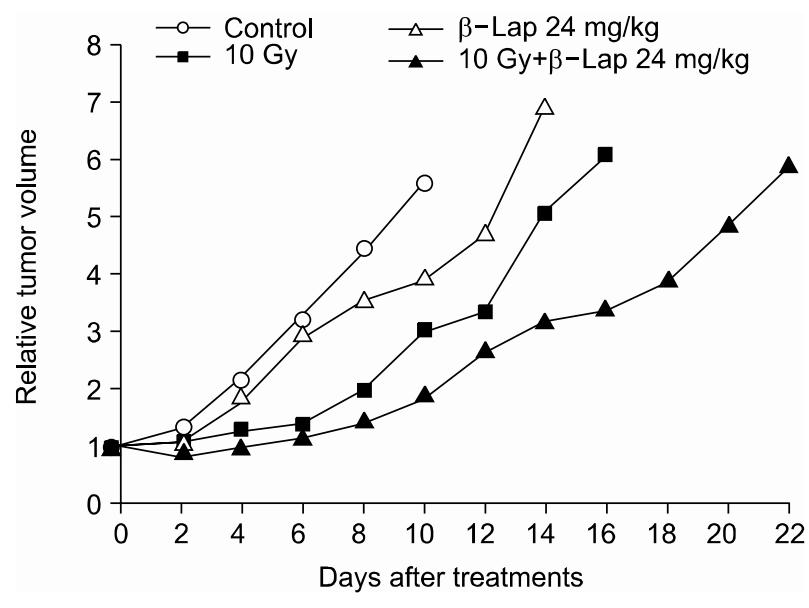

Fig. 7. Growth inhibition of RKO tumors in the thigh of BALB/cnuslc nude mice after various treatments. There were four groups of tumors: (i) Control tumors, (ii) Tumors were irradiated with $10 \mathrm{~Gy}$ in a single dose (10-Gy), (iii) Host animals were i.p. injected with $24 \mathrm{mg} / \mathrm{kg} \beta$-lap and (iv) Host animals were i.p. injected with $24 \mathrm{mg} / \mathrm{kg} \beta$-lap and the tumor irradiated $30 \mathrm{~min}$ later with $10 \mathrm{~Gy}$. The means of $5 \sim 7$ tumors, with one S.E., are shown.

B-lap alone and both in combination. An i.p. injection of 24 $\mathrm{mg} / \mathrm{kg} \beta$-lap slightly suppressed the tumor growth, but the $\beta$ lap treatment $30 \mathrm{~min}$ before tumor irradiation markedly enhanced the delay in the radiation-induced tumor growth. The numbers of days required for a 5-fold increase in mean tumor volumes of the control, $\beta$-lap alone, irradiation alone and combination groups were $8.2 \pm 0.5, \quad 11.3 \pm 0.7, \quad 12.9 \pm 0.8$ and $29.8 \pm 1.7$ days, respectively. The growth delay (difference between the control and treated groups) of 3.1 days caused by $\beta$-lap treatment alone was statistically significant $(\mathrm{p}<0.05)$. The growth delay caused by 10 Gy tumor irradiation in combination with $\beta$-lap treatment was 21.6 days, which was 18.5 and 16.9 days longer than those caused by $\beta$-lap alone and irradiation alone, respectively. The tumor volume doubling time for the control was 3.5 days, while those for the $10 \mathrm{~Gy}$ radiation and combined treatments were about 8.0 and 11.0 days, respectively. Therefore, the tumor volume doubling time increased by factors of 2.3 and 3.1, respectively, when the tumors were treated with irradiation alone and the combination treatment. It was apparent that the $\beta$-lap treatment significantly enhanced the irradiation effect in suppressing the delay in tumor growth.

\section{DISCUSSION}

Using RKO human colorectal cancer cells, we have shown that $\beta$-lap causes clonogenic cell death and apoptosis, and also sensitizes cells to radiation by inhibiting the repair of sublethal radiation damage.

The interest in $\beta$-lap, a quinone-containing natural product, has increased in recent years due to its unique ability to not only cause death in various cancer cells, but to interact synergistically with ionizing radiation and some chemotherapy drugs in killing cancer cells $(1,8,13)$. The mechanism underlying the $\beta$-lap-induced cell death has been controversial. However, it has recently been demonstrated that a two-electron reduction of $\beta$-lap, through NQO1 mediation, is probably the first reaction, which then triggers signaling transduction leading to apoptosis and clonogenic cell death $(3,5,8,9,19)$.

In our previous studies, ionizing radiation and $\beta$-lap were observed to synergistically kill cancer cells, even when cells were treated with $\beta$-lap for as long as $10 \mathrm{~h}$ after irradiation, and ionizing radiation was observed to induce long-lasting elevation of the NQO1 activity (19). Therefore, we concluded that the radiation-induced increase in the NQO1 activity sensitized the cells to $\beta$-lap. However, we could not attribute the synergistic interaction between the $\beta$-lap when applied soon after irradiation in the radiation-induced sensitization of cells to $\beta$-lap, since a significant increase in the NQO1 activity took $3 \sim 4 \mathrm{~h}$ after irradiation. This observations lead us to hypothesize that $\beta$-lap inhibits SLD repair, thereby sensitizing cells to radiation. The results obtained in the present study indeed support our hypothesis. 
As shown in Fig. 1 and 3, B-lap treatment alone caused clonogenic death and apoptosis in RKO cells. The clonogenic survival of RKO cells decreased to about $2.9 \%$ when cells were treated with $10 \mu \mathrm{M}$ B-lap for $4 \mathrm{~h}$. The results shown in Fig. 3 demonstrates that apoptotic DNA degradation could be detected at the end of a $4 \mathrm{~h}$ incubation with $5 \mu \mathrm{M}$ B-lap, with massive apoptosis occurring by $16 \mathrm{~h}$, i.e. $12 \mathrm{~h}$ after $\beta$-lap treatment. Conversely, no significant apoptosis was detected $24 \mathrm{~h}$ after 2 4 Gy irradiation. These results were in good agreement with that of the flow cytometric analysis shown in Fig. 5, in that about $60 \%$ of cells died due to apoptosis within $24 \mathrm{~h}$ of treatment with $5 \mu \mathrm{M}$ B-lap, while no apoptosis occurred $24 \mathrm{~h}$ after 4 Gy irradiation. Importantly, the rapid apoptosis caused by $\beta$-lap occurred independent of the cycle phases (Fig. 5), implying that cells in different cell cycle phases were equally sensitive to $\beta$-lap.

The results shown in Fig. 2 clearly demonstrate that the radiosensitivity of RKO cells increased when the cells were treated with $\beta$-lap for $4 \mathrm{~h}$ soon after the irradiation. In this regard, in a previous study (19) we observed that treating cells with $\beta$-lap before irradiation caused no change in the radiosensitivity of the cells. As shown in Fig.3, the clonogenic survival of RKO cells irradiated with $6 \mathrm{~Gy}$, in two equal 3 Gy doses separated by $1 \mathrm{~h}$, was almost 3 -fold greater than that of cells irradiated with a single 6 Gy exposure. It was apparent that substantial repair of the SLD was caused by the first 3 Gy irradiation during the first hour after irradiation. However, such an increase in cell survival due to repair of SLD was almost completely prevented when cells were maintained in $8 \mu \mathrm{M} \beta$ lap during the $1 \mathrm{~h}$ interval between the two radiation exposures. It is a well-known fact that cells are arrested in G2 phase after irradiation exposure, and radiation-induced DNA damage is repaired during the G2 arrest (22). As demonstrated in Fig. 5, irradiation with 4 Gy induced a profound G2 arrest in RKO cells, and $\beta$-lap treatment completely prohibited the induction of radiation-induced G2 arrest. These results may be interpreted as $\beta$-lap inhibiting the SLD repair by prohibiting the induction of $\mathrm{G} 2$ arrest in irradiated cells. The $\beta$-lap-induced apoptosis that occurred in all cell cycle phases, in both unirradiated and irradiated cells, may also have an association.

The apoptosis and cell cycle progression after cell damage are intimately related to the functional stati of p53 and p21. It is highly likely that the profound suppression of the p53 and p21 activities by $\beta$-lap is related to the rapid and marked induction of apoptosis (Fig. 4 and 5), i.e. the complete prohibition of induction of radiation-induce G2 arrest (Fig. 5, 6), by $\beta$-lap treatment. Cyclin B1-Cdc2 kinase has been known to be involved in the progression of cells from the G2 phase to mitosis. Irradiation with 4 Gy caused a progressive increase in the cyclin B1-Cdc2 kinase activity during the $24 \mathrm{~h}$ post-irradiation period, while $\beta$-lap treatment caused progressive decline in the cyclin B1-Cdc2 kinase activity (Fig. 6). The changes in cyclin B1-Cdc2 kinase activity in the cells irradiated and treated with $\beta$-lap were similar to those in the cell treated with $\beta$-lap alone. We previously reported that an increase in the $\mathrm{G} 2$ cell population after irradiation increased the cyclin B1-Cdc2 kinase activity, which in turn, accelerated the exit of cells from the $\mathrm{G} 2$ phase to mitosis (21). It is tempting to conclude that the progressive decline in the $\mathrm{G} 2$ cell population after $\beta$-lap treatment removed the necessity for an increase in the cyclin B1-Cdc2 kinase activity in both non-irradiated and irradiated cells.

An i.p. injection of $24 \mathrm{mg} / \mathrm{kg}$-lap to BALB/c-nuslc nude mice caused small, but noticeable, inhibition of the growth of RKO tumors established in the hind leg, and significantly enhanced the delay in the radiation-induced tumor growth. A comparison of the extent of growth delay caused by $\beta$-lap alone, irradiation alone and the combination of these two treatments indicated that the combined effect of $\beta$-lap and irradiation was greater than the sum of the individual effects. These results may imply that radiosensitization, in addition to cell death, played an important role in the impressive delay in tumor growth caused by the combination of $\beta$-lap and irradiation. With respect to this, it is important to note that the NQO1 activity in malignant tumors is far greater that that in the adjacent normal tissues (25), indicating that $\beta$-lap-induced cell death and radiosensitization may occur preferentially in malignant tumors. Further in vivo studies are in progress in our laboratory to reveal the various factors involved in the response of tumors to $\beta$-lap treatment alone or in combination with radiotherapy, such as the dose and administration time of $\beta$-lap in relations to tumor irradiation.

\section{CONCLUSIONS}

B-lap is known to be cytotoxic against various human cancer cells. The results of the present study clearly demonstrated that $\beta$-lap sensitizes cancer cells to radiation by inhibiting the repair of sublethal radiation damage. The combined effect of $\beta$-lap and irradiation in the suppression of tumor growth in vivo was more than additive; probably in part, due to the $\beta$-lap-induced radiosensitization. $\beta$-lap is a potentially useful potent anti-cancer chemotherapy drug and a potent radiosensitizer against caner cells also.

\section{REFERENCES}

1. Pardee AB, Li YZ, Li CJ. Cancer therapy with $\beta$-lapachone. Curr Cancer Drug Targets. 2002;2:227-42.

2. Planchon SM, Wuerzberger S, Frydman B, Witiak DT, Hutson $\mathrm{P}$, Church DR, et al. B-lapachone-mediated apoptosis in human promyelocytic leukemia (HL-60) and human prostate cancer cells: a p53-independent response. Cancer Res. 1995; 55:370611.

3. Tagliarino C, Pink JJ, Dubyak GR, Nieminen AL, Boothman DA. Calcium is a key signaling molecule in beta-lapachonemediated cell death. J Biol Chem. 2001;276:19150-9.

4. Wuerzberger S, Pink JJ, Planchon SM, Byers KL, Bornmann WG, Boothman DA. Induction of apoptosis in MCF-7: WS8 breast cancer cells by beta-lapachone. Cancer Res. 1998;58: 1876-85.

5. Pink JJ, Wuerzberger-Davis S, Tagliarino C, Planchon SM, Yang $\mathrm{X}$, Froelich CJ, et al. Activation of a cysteine protease in MCF-7 and T47D breast cancer cells during $\beta$-lapachone mediated apoptosis. Exp Cell Res. 2000;25:144-55.

6. Li CJ, Li YZ, Pinto AV, Pardee AB. Potent inhibition of tumor 
survival in vivo by beta-lapachone plus taxol: combining drugs imposes different artificial checkpoints. Proc Natl Acad Sci USA. 1999;96:13369-74.

7. Boothman DA, Trask DK, Pardee AB. Inhibition of potentially lethal DNA damage repair in human tumor cells by betalapachone, an activator of topoisomerase I. Cancer Res. 1989; 49:605-12.

8. Pink JJ, Planchon SM, Tagliarino C, Varnes ME, Siegel D, Boothman DA. $\mathrm{NAD}(\mathrm{P}) \mathrm{H}$ : Quinone oxidoreductase activity is the principal determinant of beta-lapachone cytotoxicity. J Biol Chem. 2000;275:5416-24.

9. Planchon SM, Pink JJ, Tagliarino C, Bornmann WG, Varnes ME, Boothman DA. B-lapachone-induced apoptosis in human prostate cancer cells: involvement of NQO1/xip3. Exp Cell Res. 2001;267:95-106.

10. Planchon SM, Wuerzberger-Davis SM, Pink JJ, Robertson KA, Bornmann WG, Boothman DA. Bcl-2 protects against betalapachone-mediated caspase 3 activation and apoptosis in human myeloid leukemia (HL-60) cells. Oncol Rep. 1999;6:485-92.

11. Li YZ, Li CJ, Pinto AV, Pardee AB. Release of mitochondrial cytochrome $\mathrm{C}$ in both apoptosis and necrosis induced by $\beta$ lapachone in human carcinoma cells. Mol Med. 1999;5:232-9.

12. Huang L, Pardee AB. Beta-lapachone induces cell cycle arrest and apoptosis in human colon cancer cells. Mol Med. 1999;5: 711-20.

13. Li Y, Sun X, La Mont JT, Pardee AB, Li CJ. Selective killing of cancer cells by $\beta$-lapachone direct checkpoint activation as a strategy against cancer. Proc Natl Acad Sci. 2003;100:2674-8.

14. Boorstein RJ, Pardee AB. Beta-Lapachone greatly enhances MMS lethality to human fibroblasts. Biochem Biophys Res Commun. 1984;118:828-34.

15. Kumi-Diaka J. Chemosensitivity of human prostate cancer cells PC3 and LNCaP to genistein isoflavone and beta-lapachone. Biol Cell. 2002;94:37-44.

16. Miyamoto S, Huang TT, Wuerzberger-Davis S, Bornmann G,
Pink JJ, Tagliarino C, et al. Cellular and molecular responses to topoisomerase I poisons. Exploiting synergy for improved radiotherapy. Ann NY Acad Sci. 2000;922:274-92.

17. Boothman DA, Greer S, Pardee AB. Potentiation of halogenated pyrimidine radiosensitizers in human carcinoma cells by beta-lapachone (3,4-dihydro-2,2-dimethyl-2H-naphtho[1,2-b] pyran-5,6-dione), a novel DNA repair inhibitor. Cancer Res. 1987;47:5361-6.

18. Boothman DA, Pardee AH. Inhibition or radiation-induced neoplastic transformation by beta-lapachone. Proc Natl Acad Sci USA. 1989;86:4963-7.

19. Park HJ, Ahn KJ, Ahn SD, Choi E, Lee SW, Williams B, et al. Susceptibility of cancer cells to $\beta$-lapachone in enhanced by ionizing radiation. Int J Radiat Oncol Biol Phys. 2005;61: 212-9.

20. Boothman DA, Meyers M, Fukunaga N, Lee SW. Isolation of $\mathrm{X}$-ray-inducible transcripts from radioresistant melanoma cells. Proc Natl Acad Sci USA. 1993;90:7200-4.

21. Park HJ, Lyons JC, Ohtsubo T, Song CW. Cell cycle progression and apoptosis after irradiation in an acidic environment. Cell Death Differ. 2000;7:729-38.

22. Hall EJ. Radiobiology for the radiologist. 5th ed. Lippincott Williams \& Wilkins, 2000.

23. Choi EK, Song H-J, Park MS, Kim BG. Influence of estrogen and polyamines on mifepristone-induced apoptosis in prostate cancer cells. Cancer Res Treat. 2004;36:85-90.

24. Griffin RJ, Williams BW, Wild R, Cherrington JM, Park H, Song CW. Simultaneous inhibition of the receptor kinase activity of vascular endothelial, fibroblast, and platelet-derived growth factors suppresses tumor growth and enhances tumor radiation response. Cancer Res. 2002;62:1702-6.

25. Siegel D, Franklin WA, Ross D. Immunohistochemical detection of $\mathrm{NAD}(\mathrm{P}) \mathrm{H}$ :quinone oxidoreductase in human lung and lung tumors. Clin Cancer Res. 1998;4:2065-70. 